\title{
Profil Sindrom Nefrotik pada Ruang Perawatan Anak RSUP Sanglah Denpasar
}

\author{
GAP Nilawati \\ Departemen Ilmu Kesehatan Anak Fakultas Kedokteran Universitas Udayana/RSUP Sanglah, Denpasar
}

\begin{abstract}
Latar belakang. Sindrom nefrotik merupakan salah satu penyakit ginjal yang sering dijumpai pada anak, ditandai dengan proteinuria, hipoalbuminemia, edema, dan hyperkolesterolemia.

Tujuan. Untuk mengetahui karakteristik, gambaran klinis, dan laboratorium anak dengan sindrom nefrotik.

Metode. Penelitian deskriptif retrospektif, dengan mengambil data dari rekam medis pasien sindrom nefrotik selama periode 2001-2007, di Bagian Ilmu Kesehatan Anak RSUP Sanglah, Denpasar.

Hasil. Selama periode 6 tahun (2001-2007), terdapat 68 anak dengan sindrom nefrotik. Usia berkisar dari 6 bulan sampai dengan 11 tahun (rerata 5,1),laki-laki 50 (73,5\%), perempuan 18 (26,5\%) dengan rasio 2,7:1. Sebagian besar pasien datang dengan keluhan utama bengkak 62 (91\%), demam 2 (3\%), kejang 2 (3\%), dan syok $2(3 \%)$. Kadar albumin rata-rata 1,02 $\pm 0,67$, kolesterol 485,3 $\pm 162,39,14,7 \%$ dengan hematuria. Peningkatan kreatinin 16 (23,5\%), respons terhadap terapi 58 (85,2\%) sensitif steroid, 10 (14,8\%) resisten steroid.

Kesimpulan. Sindrom nefrotik lebih banyak mengenai laki-laki dibandingkan perempuan. Sebagian besar pasien datang ke rumah sakit dengan keluhan bengkak dan proteinuria masif. Respons pengobatan menunjukkan sebagian besar sensitif terhadap steroid. Sari Pediatri 2012;14(4):269-72.
\end{abstract}

Kata kunci: sindrom nefrotik, bengkak, sensitif steroid, resisten steroid

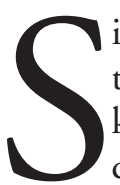
indrom nefrotik $(\mathrm{SN})$ merupakan kelainan ginjal terbanyak dijumpai pada anak, dengan angka kejadian 15 kali lebih banyak dibandingkan orang dewasa. Insidennya sekitar 2-3/100.000 anak per tahun, dan sebagian besar anak SN merupakan tipe sensitif terhadap pengobatan steroid yang dimasukkan sebagai kelainan minimal. ${ }^{1-4}$

\section{Alamat korespondensi:}

Dr. Gusti Ayu Putu Nilawati, Sp.A. Divisi Nefrologi Bagian Ilmu Kesehatan Anak FK UNUD/RSUP Sanglah Denpasar, Telp. (0361) 227911, E-mail:drnilaspa@gmail.cpm,mbokya@yahoo.com
Gambaran klinis SN ditandai dengan proteinuria masif $\left(>40 \mathrm{mg} / \mathrm{m}^{2} / \mathrm{jam}\right)$, hipoalbuminemia $(<2,5 \mathrm{~g} /$ $\mathrm{dL}$ ), edema, dan hiperlipidemia. ${ }^{2-3}$ Sebagian besar (90\%) SN pada anak-anak merupakan SN yang idiopatik. Sisanya (10\%) merupakan SN sekunder yang berhubungan dengan kelainan glomerulus seperti nefropati membranosa dan glomerulonefritis membranoprolifratif.

Sindrom nefrotik terjadi karena peningkatan permeabilitas dinding kapiler glomerulus yang mengakibatkan proteinuria masif dan hipoalbuminemia. Penyebab peningkatan permeabilitas dinding kapiler 
tersebut belum diketahui dengan pasti. ${ }^{4,5}$ Mekanisme terjadinya edema pada SN diakibatkan protein yang hilang lewat urin sehingga mengakibatkan hipoalbuminemia, selanjutnya terjadi penurunan tekanan onkotik plasma yang mengakibatkan perpindahan cairan dari ruang intravaskular ke ruang interstisial. ${ }^{6,7}$

Diagnosis SN ditegakkan berdasarkan gejala klinis yang seringkali ditandai dengan edema yang timbul pertamakali pada daerah sekitar mata dan ekstremitas bagian bawah. Selanjutnya edema semakin meluas yang ditandai dengan asites efusi pleura, dan edema pada daerah genital. Seringkali dijumpai dengan gejala anokreksia, nyeri perut dan diare. Pada kasus lain dapat disertai hipertensi maupun hematuria gross. ${ }^{2,3}$ Hasil pemeriksaan urin menunjukkan proteinuria $3+$ atau $4+$ atau protein dalam urin $>40 \mathrm{mg} / \mathrm{m}^{2} / \mathrm{jam}$; pada $20 \%$ kasus dapat dijumpai hematuria mikroskopik. Kadar albumin serum umum berkurang dari $2,5 \mathrm{~g} /$ dL dan terjadi peningkatan kolesterol dengan kadar C3 maupun C4 normal.

Pengobatan SN anak yang baru pertama kali kena dengan gejala edema ringan dapat dilakukan rawat jalan. Anak SN pada rentan usia 1-8 tahun diduga merupakan SN kelainan minimal. Oleh karena itu pasien dapat diobati tanpa didahului dengan biopsi ginjal. Sebagian besar pasien dengan SN kelainan minimal akan mengalami kekambuhan dan frekuesi relaps akan menurun sesuai dengan umur yang bertambah.

Penelitian dilakukan dengan tujuan untuk mencari karakteristik, gambaran klinis, dan labolatorium pasien sindrom nefrotik yang di rawat di bagian Ilmu Kesehatan Anak RSUP Sanglah, Denpasar.

\section{Metode}

Penelitian deskriptif retrospektif, dilakukan di Divisi Nefrologi Bagian Ilmu Kesehatan Anak (IKA) FK UNUD/ RSUP Sanglah, Denpasar. Data diambil dari rekam medis pasien sindrom nefrotik selama periode 2001- 2007. Semua pasien dengan diagnosis sindrom nefrotik dimasukkan dalam penelitian ini. Kriteria inklusi adalah semua pasien usia $>1$ tahun dan $<12$ tahun dengan diagnosis sindrom nefrotik, yang ditegakkan berdasarkan gejala klinis dan laboratorium, yaitu keluhan bengkak pada kelopak mata, tungkai maupun seluruh tubuh, disertai pemeriksaan laboratorium hipoalbuminemia (kadar albumin $<2,5 \mathrm{~g} / \mathrm{dL}$ ), proteinuria masif $(>40 \mathrm{mg} /$ $\mathrm{m}^{2} \mathrm{LPB} / \mathrm{jam}$ atau dipstik $\geq 2+$ ), dan hiperkolesterolemia (kolesterol $>200 \mathrm{mg} / \mathrm{dL}$ ).

Data yang dicatat meliputi umur saat gejala pertama kali, jenis kelamin, keluhan awal, tekanan darah, hasil laboratorium urin, albumin, kolesterol, ureum, kreatinin. Interpretasi tekanan darah adalah nilai sistol dan diastol sesuai dengan umur, tinggi badan, dan jenis kelamin. Respons terapi dicatat sebagai sensitif steroid, apabila dengan pengobatan steroid dosis penuh $(2 \mathrm{mg} / \mathrm{kgBB} / \mathrm{h}$ ari atau $60 \mathrm{mg} / \mathrm{LPT})$ selama empat minggu mengalami remisi, sedangkan resisten steroid apabila dengan pengobatan di atas tidak berespon.

\section{Hasil}

Sejak Januari 2001 sampai Desember 2007, pasien sindrom nefrotik baru yang dirawat di Bagian IKA FK UNUD/RSUP Sanglah Denpasar tercatat 68 kasus. Rentang usia adalah 6 bulan sampai dengan 11 tahun. Sebagian besar dijumpai pada laki-laki 50 $(73,5 \%)$, dan perempuan $18(26,5 \%)$ dengan rasio

Tabel 1. Distribusi pasien berdasarkan jenis kelamin dan umur

\begin{tabular}{lccc}
\hline $\begin{array}{c}\text { Umur } \\
\text { (tahun })\end{array}$ & $\begin{array}{c}\text { Laki-laki } \\
(\%)\end{array}$ & $\begin{array}{c}\text { Perempuan } \\
(\%)\end{array}$ & Total \\
\hline $1-4$ & $10(20)$ & $2(11,1)$ & $12(17,6)$ \\
$5-9$ & $37(74)$ & $15(83,3)$ & $52(76,4)$ \\
$\geq 10$ & $3(6)$ & $1(5,6)$ & $4(6)$ \\
Total & $50(73,5)$ & $18(26,5)$ & $68(100)$ \\
\hline
\end{tabular}

Tabel 2. Gejala klinis yang dijumpai pada pasien saat pertama datang

\begin{tabular}{lc}
\hline Gejala klinis & Jumlah (\%) \\
\hline Bengkak & $62(91)$ \\
Demam & $2(3)$ \\
Kejang & $2(3)$ \\
Syok & $2(3)$ \\
\hline
\end{tabular}

Tabel 3. Gambaran laboratorium

\begin{tabular}{lc}
\hline Pemeriksaan laboratorium & Rerata \\
\hline Albumin $(\mathrm{g} / \mathrm{dL})$ & $1,02 \pm 0,67$ \\
Kolesterol $(\mathrm{mg} / \mathrm{dL})$ & $485,3 \pm 162,39$ \\
Hematuria $(\%)$ & 14,7 \\
\hline
\end{tabular}


3:1. Pasien umumnya datang dengan keluhan bengkak pada kelopak mata, tungkai maupun bengkak pada seluruh tubuh (91\%), dan yang lain datang dengan keluhan demam 2 (3\%), kejang 2 (3\%), dan dengan syok $2(3 \%)$. Kadar albumin rata-rata $1,02 \pm 0,67 \mathrm{~g} /$ $\mathrm{dL}$, kolesterol 485,3 $\pm 162,39 \mathrm{mg} / \mathrm{dL}$. Peningkatan ureum terdapat $59(86,7 \%)$ dan peningkatan kreatinin $16(23,5 \%)$. Hematuria dijumpai pada $14,7 \%$ kasus. Proteinuria dengan tes dipstik sebagian besar $>+3$.

\section{Pembahasan}

Sindrom nefrotik (SN) adalah sindrom klinis akibat perubahan selektifitas permeabilitas dinding kapiler glomerulus sehingga protein dapat keluar melalui urin. Pada anak SN merupakan penyakit ginjal yang paling sering ditemukan. Di Indonesia dilaporkan 6 per 100.000 per tahun dengan perbandingan anak laki-laki dan perempuan 2:1. Perbandingan kasus pada laki-laki lebih banyak dibandingkan perempuan, lebih banyak berlaku pada masa anak dan rasio tersebut berubah pada SN yang dijumpai pada remaja dan usia dewasa. ${ }^{2,3}$ Divisi Nefrologi Anak Ilmu Kesehatan Anak RS Cipto Mangunkusumo (RSCM) mencatat sekitar 130 kasus baru selama 4 tahun periode 2004-2008. Kami mendapatkan 68 kasus sindrom nefrotik baru selama periode 6 tahun (2001-2007) dengan perbandingan laki-laki dan perempuan 3:1. Ahmadzadeh $\mathrm{dkk}^{12}$ juga menyatakan lebih banyak ditemukan pada laki-laki dibandingkan perempuan 2:1.

Gejala sindrom nefrotik biasanya datang dengan edema palpebra dan pretibia. Edema palpebra timbul pada saat bangun tidur, semakin siang edema palpebra akan semakin berkurang namun akan tampak edema pretibia. Apabila lebih berat akan disertai asites, edema skrotum/labia, dan efusi pleura. Ketika sudah terdapat efusi pleura dapat timbul gejala sesak napas. Asites dan sesak napas sering menyebabkan anak menjadi rewel, tidak mau makan, tampak lemah, nyeri perut, dan gejala lain. Protein yang terdapat dalam urin menyebabkan urin menjadi berbuih. Gejala lain yang dapat timbul namun jarang terjadi misalnya hipertensi, hematuria, diare, dan lain-lain. Pada sindrom nefrotik sekunder akan disertai gejala penyakit dasarnya.

Pada penelitian kami sebagian besar pasien datang dengan keluhan bengkak di kelopak mata, tungkai maupun bengkak di seluruh tubuh dan yang lain datang dengan keluhan demam, kejang, dan dengan syok
Pemeriksaan penunjang yang paling diperlukan adalah pemeriksaan protein urin, kadar albumin, dan kadar kolesterol darah. Pemeriksaan protein urin dapat dilakukan dengan pemeriksaan urin yang paling sederhana yaitu pemeriksaan urin dengan dipstik. Pemeriksaan tersebut merupakan pemeriksaan urin semi quantitatif, Dengan hasil $1+(-15 \mathrm{mg} / \mathrm{dL}), 2+$ $(-100 \mathrm{mg} / \mathrm{dL})$ dan $3+(-300 \mathrm{mg} / \mathrm{dL})$. Pada sindrom nefrotik tes dipstik menunjukkan proteinuria $\geq 2+$. Pada penelitian kami protenuria dengan menggunakan tes dipstik menunjukkan hasil rata-rata $\geq 3+$.

Pada SN terjadi penurunan albumin serum, yang merupakan akibat proteinuria dan ketidakmampuan hati dalam meningkatkan sintesis albumin. Hati meningkatkan sintesis albumin empat kali lipat dengan cara meningkatkan transkripsi messenger RNA, dan menurunkan katabolisme protein di seluruh tubuh. Tetapi setiap albumin yang dibentuk akan dikatabolisme setiap saat terjadi peningkatan albumin, akibat respon epitel tubulus ginjal terhadap albuminuria. ${ }^{4,9}$ Akibatnya, katabolisme dan ekskresi albumin selalu lebih tinggi dari kemampuan hati untuk menjaga kadar normal serum albumin dan tekanan onkotik intravaskular. Pada penelitian kami kadar albumin plasma berkisar 1,02 $\pm 0,67 \mathrm{~g} / \mathrm{dL}$ dengan kadar kolesterol 485,3 $\pm 162,39 \mathrm{mg} / \mathrm{dL}$.

Kreatinin serum pada SN dapat menunjukkan hasil yang rendah, normal maupun eningkat. Kreatinin serum yang rendah merupakan akibat hiperfiltrasi pada glomerulus. Pada penelitian kami peningkatan kreatinin terjadi pada $16(23.5 \%)$ kasus. International study of kidney disease in children (ISKDC) melaporkan antara 1/3-1/2 kasus SN idiopatik menunjukkan kadar kreatinin lebih tinggi dari persentil 98 sesuai dengan umurnya. Laporan lain peningkatan kreatinin terjadi pada 32,5\% pasien dengan $S N$ kelainan minimal, 40,6\% pasien dengan glomerulosklerosis fokal segmental (GSFS), dan 50\% pasien dengan glomerulonefritis membranoproliferatif (MPGN). ${ }^{10,11}$ Pada penelitian kami tidak dilakukan biopsi, sehingga peningkatan kadar kreatinin tidak dibedakan berdasarkan temuan patologi anatominya.

Berdasarkan respons terapi terhadap steroid, 85,2\% menunjukkan sensitif steroid. Hasil tersebut sedikit lebih rendah dari penelitian Ahmadzadeh dkk ${ }^{12}$ yang menjumpai $87 \%$ sensitif steroid, sedangkan Bircan $\mathrm{dkk}^{8}$ menjumpai $86,84 \%$ merupakan sensitif steroid. Kekurangan dari penelitian kami adalah keterbatasan data yang diperoleh dari rekam medik dan tidak semua 
data tercatat secara lengkap. Sebagai kesimpulan, sebagian besar kasus SN di Rumah Sakit Sanglah Denpasar mengenai laki-laki dan sebagian besar mempunyai respons yang sensitif terhadap steroid.

\section{Daftar pustaka}

1. Bagga A, Mantan M. Nephrotic syndrome in children. Indian J Med Res 2005;122:13-28.

2. Trihono PP, Alatas H, Tambunan T, Pardede SO. Konsensus tata laksana sindrom nefrotik idiopatik pada anak. Unit Kerja Koordinasi Nefrologi Ikatan Dokter Anak Indonesia. Jakarta: Badan Penerbit IDAI; 2008.

3. Wirya IGNW. Sindrom nefrotik. Dalam: Alatas H, Tambunan T, Trihono PP, Pardede SO, penyunting. Buku ajar nefrologi anak. Edisi kedua. Jakarta: Balai Penerbit FKUI 2004.h.381-426.

4. Niaudet P. Steroid-sensitive idiopathic nephritic syndrome. Dalam: Avner ED, Harmon WE, Niaudet P. Pediatric nephrology. Edisi ke-5. Philadelphia: Lippincott Williams \& Wilkins; 2004.h.545-73.

5. Ozkaya N, Cakar N, Ekim M, Kara N, Akkok N,
Yalcinkaya F. Primary nephrotic syndrome during childhood in Turkey. Pediatr Int 2004;46:436-8.

6. Behrman RE, Kliegman RM, Jenson HB, penyunting. Nephrotic syndrome. Dalam: Nelson Textbook of Pediatrics. Edsis ke-17. Philadelphia: Saunders; 2004.h.1753-8.

7. Coovadia HM, Eke F, Luta M, eds. Nephrotic syndrome. Dalam: Pediatric nephrology. Edisi ke-4. Baltimore: Lippincott Williams and Wilkins; 1999.h.1362-7.

8. Bircan Z, Yavuz A, Katar S. Childhood idiopathic nephrotic syndrome in Turkey. Pediatr Int 2002;44:60811.

9. Okoro BA, Okafor HU. Childhood nephrotic syndrome in Enugu, Nigeria. West Afr J Med 2000;19:137-41.

10. Adedoyin OT, Gbelee HOD, Adeniyi A. Childhood nephrotic syndrome in Ilorin. Nig J Paed 2001;28:6872.

11. Kevin DM, David BK, William ES. Pediatric steroidresistant nephrotic syndrome. Curent Probl Pediatr 2001; 31:275-307.

12. Ahmadzadeh A, Derakhshan A, Hakimzadeh M, Zolfigol A. Idiopathic nephrotic syndrome in Iranian children. Indian pediatrics 2008; 45:52-3. 